\section{Performance of Yellow-flowering Magnolias in Zone 6b}

\author{
Donna C. Fare F $^{1,2}$
}

Additional INDEx words. Magnolia denudata, Magnolia acuminata, deciduous magnolia

SUMMARY. Yellow-flowering magnolias (Magnolia sp.) were evaluated for flower color, bloom duration, and growth rate in U.S. Department Agriculture (USDA), Hardiness Zone 6b, McMinnville, TN. Of the $\mathbf{3 0}$ cultivars evaluated, all were reported to have yellow blooms; however, tepal color ranged from light pink with some yellow coloration, creamy yellow to dark yellow. 'Daphne', 'Judy Zuk', and 'Yellow Bird' had the highest yellow color readings on the outside of the tepal and would often be among the latest cultivars to bloom. Magnolia cultivars Gold Star, Golden Gala, Stellar Acclaim, Sun Spire, and Sundance had the lightest yellow tepal color on the outside of the tepal. 'Goldfinch', 'Butterflies', and 'Elizabeth' were the earliest to bloom; 'Elizabeth' had one of the longest flowering periods. 'Carlos' and 'Gold Star' were two of the tallest cultivars in the test compared with Butterflies, Gold Cup, Golden Gift, Golden Pond, Golden Rain, Green Bee, Honey Liz, Koban Dori, Skyland's Best, and Sunsation, which had the least height growth. Trunk diameters ranged from 7.4 to $18.4 \mathrm{~cm}$ after 9 years in the evaluation. Cultivars Golden Gala and Gold Star had trunk diameters greater than twice the size of Golden Pond, Golden Rain, Green Bee, Honey Liz, and Koban Dori. Powdery mildew (Phyllactinia corylea and Microsphaera alni) was observed on all cultivars; however, Golden Sun, Green Bee, Solar Flair, Stellar Acclaim, Sunburst, and Yellow Bird had greater than $47 \%$ of the leaf area affected with powdery mildew. Over $60 \%$ of the canopy was affected with powdery mildew on 'Green Bee', 'Stellar Acclaim', 'Sunburst', and 'Yellow Bird'. Powdery mildew was less than $20 \%$ on both the foliage and plant canopy of 'Banana Split', 'Butterflies', 'Carlos', 'Elizabeth', and 'Sun Spire'.

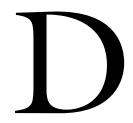
eciduous magnolias are well adapted to many landscape situations and are highly desirable due to their floriferous nature. About 800,000 flowering magnolias are sold each year in the United States and about $10 \%$ of the nurseries that grow magnolias are located in Tennessee (USDA, 2014). There has been interest in breeding for deciduous yellow-flowering magnolias since the 1950s. Most of the yellow-flowering magnolias have been bred from a U.S. native magnolia, cucumber magnolia (Magnolia acuminata), or a smaller statured botanical variety of the species, yellow cucumber magnolia $(M$. acuminata var. subcordata). This species provides cold hardiness and can be grown in a wide array of soil types. Hybridization with Chinese magnolias [yulan magnolia (Magnolia denudata) or lily magnolia (Magnolia

USDA-ARS, U.S. National Arboretum, Tennessee State University Nursery Research Center, 472 Cadillac Lane, McMinnville, TN 37110

${ }^{1}$ Research Horticulturist

${ }^{2}$ Corresponding author. E-mail: donna.fare@ars.usda. gov

doi: 10.21273/HORTTECH03576-16 liliflora)] can offer yellow flower color and a range of tree sizes and shapes. Most American magnolias bloom with the foliage, which means a late spring-summer bloom; whereas, the Chinese magnolias bloom before the leaves emerge in the spring. Many cultivars of the yellow magnolias bloom in late March to early April, but often spring frosts and freezes affect flowering as well as leaf-out (Fare, 2011). Cultivars such as Elizabeth, Yellow Bird, and Butterflies were a few of the first commercially available. A second generation of yellow-flowering magnolias with cultivars such as Golden Sun, Golden Gift, Gold Star, and Yellow Lantern were developed by breeders D. Leach and P. Savage; A. Kehr released 'Gold Cup', 'Solar Flair', 'Stellar Acclaim', 'Sundance', and 'Sun Ray' and in later years, released
'Sunburst', 'Sunsation', and 'Sun Spire'. One notable cultivar, Lois, was developed by L. Koerting (Knox, 2001). Yellow-flowering deciduous magnolias are becoming popular landscape plants because they offer an unusual color palette and there are very few yellow-flowering small trees in the landscape plant inventory (Knox, 2002).

This evaluation was conducted at the Tennessee State University Nursery Research Center located in McMinnville, TN (lat. $35.7^{\circ} \mathrm{N}$, long. $85.8^{\circ} \mathrm{W}$ ) on the border of USDA Hardiness Zones 6 and 7. The area is known as a climatic and geographic transition zone. Plants produced in this area can be used in landscapes as far north as Zone 5 and as far south as Zone 8. Plant evaluations made in transition zones are ideal because results can be used over a wide geographic and climatic area. The primary objective of this research project was to compare yellow-flowering magnolias for flower color intensity, flower duration, as well as growth rate and canopy form.

\section{Materials and methods}

Plant evaluation. Many cultivars of yellow-flowering magnolias were only available in low numbers and small sizes so plants for this evaluation were purchased, grown in a no. 3 or no. 5 container for 1 year, then planted in the evaluation plot the following spring. The first plantings were in Mar. 2006 in a field plot with well-drained silt loam soil (Waynesboro) with a 15 -ft in-row spacing and 12 -ft between-row spacing. Each magnolia cultivar was planted in a randomized block design with three single plant replications. Plants were maintained with traditional management including fertilization, mulching, and weed control. Pruning was limited to removing branches from the trunk about 24 inches above the soil line. In Mar. 2007, a few weeks of unseasonably warm temperatures occurred followed by a hard freeze that lasted several days. Many plants had

\begin{tabular}{llll}
\hline $\begin{array}{l}\text { Units } \\
\text { To convert U.S. to SI, } \\
\text { multiply by }\end{array}$ & U.S. unit & SI unit & $\begin{array}{l}\text { To convert SI to U.S., } \\
\text { multiply by }\end{array}$ \\
\hline 0.3048 & $\mathrm{ft}$ & $\mathrm{m}$ & 3.2808 \\
2.54 & $\begin{array}{l}\text { inch(es) } \\
\text { inch }^{2}\end{array}$ & $\begin{array}{l}\mathrm{cm} \\
\mathrm{cm}^{2}\end{array}$ & 0.3937 \\
6.4516 & $\mathrm{Cm}^{2}$ & 0.1550
\end{tabular}


broken dormancy, and as a result of the freeze, were killed or suffered severe dieback. Plantings were reestablished and up to 37 cultivars of yellow-flowering magnolias were under evaluation; however, cultivars Brenda, Illini Gold, Illini Moonlight, Miss Honeybee, Evamarie, Coral Lake, and Blue Opal, died from subsequent spring freezes with damage to the trunks and or canopy (Magnolia Society, 2010). Flowering period was determined from the time that flowers first opened until the last flowers senesced. These dates were recorded by days of the year and averaged from 2008 to 2016. To determine flower color, three flowers per tree were removed on the day the flowers opened and color was measured on the inside and outside of the tepal using the Royal Horticultural Society Color Chart (RHS, 2007) and a portable spectrophotometer (CM-2600d; Konica Minolta Sensing Americas, Ramsey, NJ). Leaf-out was recorded from the time the foliage was at least $50 \%$ unfurled until full leaf. During June 2014, five fully matured leaves located with 18 inches from the tip of the branch were randomly selected from branches located in the upper top of canopy to determine leaf area with a portable leaf area meter (CI-203; CID, Camas, WA). Powdery mildew was rated during August, September, and October each year for the percentage coverage of powdery mildew on individual leaves and the percentage of the total foliage area affected. In Dec. 2015 after leap drop, height, canopy width (an average of two canopy widths made perpendicular from dripline to dripline), and trunk diameter (measured $15 \mathrm{~cm}$ above the soil surface) were recorded. All data were statistically analyzed using the linear model in SAS (version 9.1; SAS Institute, Cary, NC). Means separation among cultivars was conducted with Duncan's multiple range test $(P \leq 0.05)$.

\section{Results and discussion}

Plant evaluation. Figure 1 shows the average period of time that flowering and leaf-out occurred from

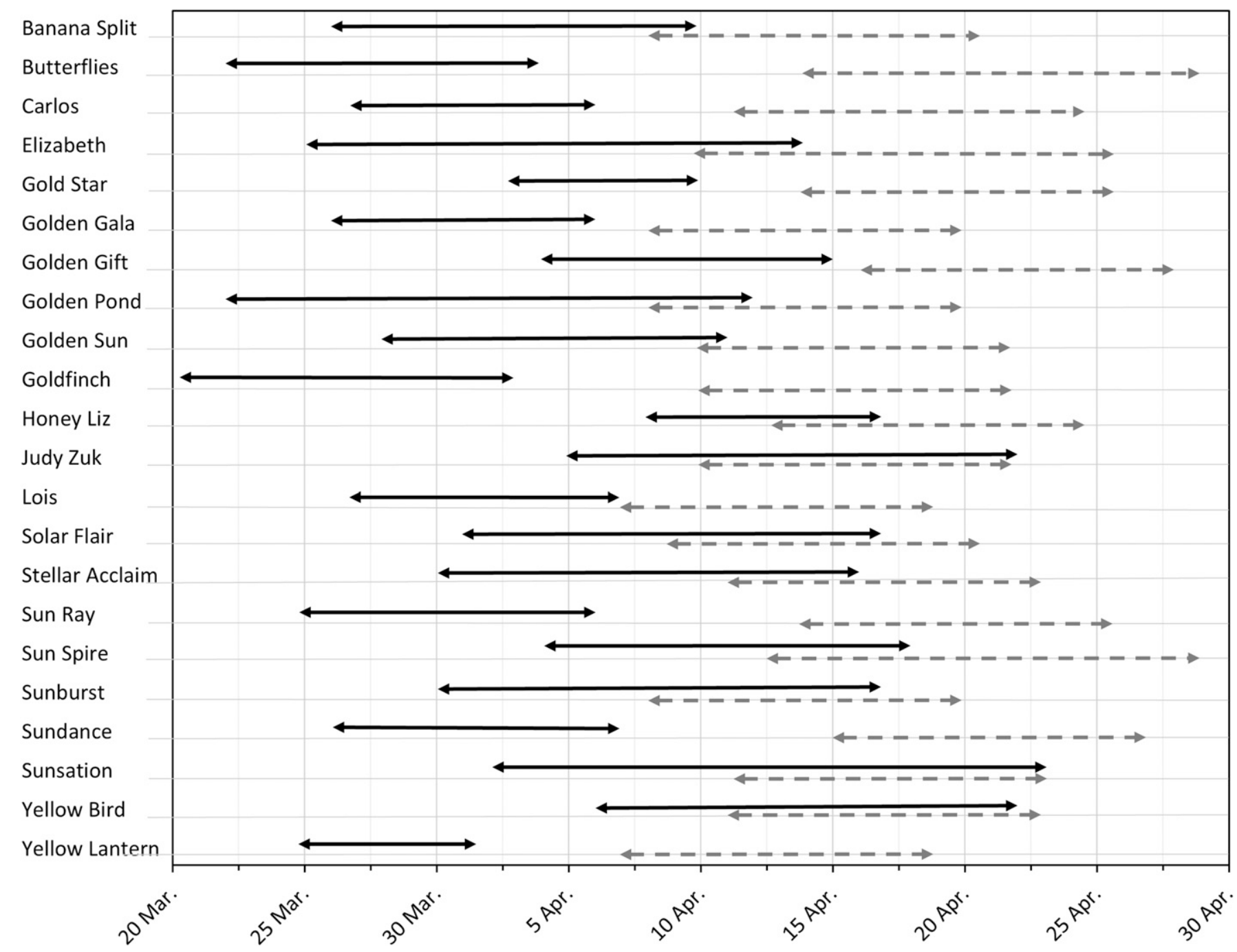

Fig. 1. Flowering and leaf-out periods of selected yellow-flowering magnolia cultivars were recorded each year by days of the year (Spring 2008 to Spring 2016) then averaged over the time period. Solid lines represent the flowering period from the time that flowers first opened until the flowers senesced. Dashed lines represent the leaf-out period from the time the foliage was at least $50 \%$ unfurled until full leaf. This evaluation was conducted at the Tennessee State University Nursery Research Center located in McMinnville, TN, on the border of USDA Hardiness Zones 6 and 7. 
Table 1. Height, canopy width, trunk diameter, and leaf area of yellow-flowering magnolia cultivars after 9 years of evaluation at McMinnville, TN (USDA Hardiness Zone 6b).

\begin{tabular}{|c|c|c|c|c|}
\hline Cultivar & $\mathrm{Ht}(\mathrm{cm})^{\mathrm{z}}$ & $\begin{array}{c}\text { Canopy } \\
\text { width }(\mathrm{cm})\end{array}$ & $\begin{array}{c}\text { Trunk } \\
\operatorname{diam}(\mathrm{cm})\end{array}$ & $\begin{array}{c}\text { Avg leaf } \\
\text { area }\left(\mathrm{cm}^{2}\right)^{y}\end{array}$ \\
\hline Anilou & $557 \mathrm{a}-\mathrm{h}^{\mathrm{x}}$ & $175 \mathrm{ghi}$ & $11.6 \mathrm{a}-\mathrm{f}$ & 177 b-e \\
\hline Banana Split & $555 \mathrm{a}-\mathrm{i}$ & $193 \mathrm{f}-\mathrm{i}$ & $12.1 \mathrm{a}-\mathrm{f}$ & $184 \mathrm{bcd}$ \\
\hline Butterflies & $444 \mathrm{~d}-\mathrm{i}$ & $180 \mathrm{ghi}$ & $9.6 \mathrm{ef}$ & $98 \mathrm{i}$ \\
\hline Carlos & $708 \mathrm{a}$ & $278 \mathrm{a}-\mathrm{h}$ & $18.2 \mathrm{ab}$ & $213 \mathrm{ab}$ \\
\hline Daphne & $491 \mathrm{~b}-\mathrm{i}$ & $209 \mathrm{e}-\mathrm{i}$ & $10.5 \mathrm{c}-\mathrm{f}$ & $99 \mathrm{i}$ \\
\hline Elizabeth & $560 \mathrm{a}-\mathrm{h}$ & $243 \mathrm{~d}-\mathrm{i}$ & $15.8 \mathrm{a}-\mathrm{e}$ & $141 \mathrm{e}-\mathrm{h}$ \\
\hline Gold Cup & $482 c-i$ & $135 \mathrm{i}$ & $10.0 \mathrm{def}$ & $123 \mathrm{f}-\mathrm{i}$ \\
\hline Gold Star & $699 \mathrm{ab}$ & $401 \mathrm{a}$ & $18.3 \mathrm{a}$ & $96 \mathrm{i}$ \\
\hline Golden Gala & $675 \mathrm{abc}$ & $346 \mathrm{a}-\mathrm{d}$ & $18.4 \mathrm{a}$ & $236 \mathrm{a}$ \\
\hline Golden Gift & $466 c-i$ & $248 c-i$ & $11.3 \mathrm{a}-\mathrm{f}$ & $90 \mathrm{i}$ \\
\hline Golden Pond & $447 \mathrm{~d}-\mathrm{i}$ & $174 \mathrm{ghi}$ & 9.0 ef & $154 \mathrm{def}$ \\
\hline Golden Rain & $345 \mathrm{i}$ & 172 ghi & $8.0 \mathrm{f}$ & $120 \mathrm{ghi}$ \\
\hline Golden Sun & $491 \mathrm{~b}-\mathrm{i}$ & $240 \mathrm{~d}-\mathrm{i}$ & $11.1 \mathrm{~b}-\mathrm{f}$ & $148 \mathrm{~d}-\mathrm{g}$ \\
\hline Goldfinch & $560 \mathrm{a}-\mathrm{h}$ & $193 \mathrm{f}-\mathrm{i}$ & $11.5 \mathrm{a}-\mathrm{f}$ & $105 \mathrm{hi}$ \\
\hline Green Bee & 355 hi & $139 \mathrm{i}$ & $7.4 \mathrm{f}$ & $95 \mathrm{i}$ \\
\hline Honey Liz & $422 \mathrm{e}-\mathrm{i}$ & $150 \mathrm{hi}$ & $8.3 \mathrm{f}$ & $178 \mathrm{~b}-\mathrm{e}$ \\
\hline Judy Zuk & $596 \mathrm{a}-\mathrm{g}$ & $193 \mathrm{f}-\mathrm{i}$ & $13.5 \mathrm{a}-\mathrm{f}$ & 192 bc \\
\hline Koban Dori & $419 \mathrm{f}-\mathrm{i}$ & 169 ghi & $7.5 \mathrm{f}$ & $87 \mathrm{i}$ \\
\hline Lois & $579 \mathrm{a}-\mathrm{g}$ & $372 \mathrm{abc}$ & $18.0 \mathrm{ab}$ & $167 \mathrm{cde}$ \\
\hline Petit Chicon & $515 a-i$ & $167 \mathrm{ghi}$ & 9.7 ef & $125 \mathrm{f}-\mathrm{i}$ \\
\hline Skyland's Best & $401 \mathrm{ghi}$ & $199 \mathrm{f}-\mathrm{i}$ & $9.6 \mathrm{ef}$ & $98 \mathrm{i}$ \\
\hline Solar Flair & $542 \mathrm{a}-\mathrm{i}$ & $284 \mathrm{a}-\mathrm{g}$ & $13.8 \mathrm{a}-\mathrm{f}$ & 109 ghi \\
\hline Stellar Acclaim & $561 \mathrm{a}-\mathrm{h}$ & $317 \mathrm{a}-\mathrm{f}$ & $13.6 \mathrm{a}-\mathrm{f}$ & $93 \mathrm{i}$ \\
\hline Sun Ray & $633 a-e$ & $354 \mathrm{a}-\mathrm{d}$ & $17.0 \mathrm{abc}$ & $164 c-f$ \\
\hline Sun Spire & $541 \mathrm{a}-\mathrm{i}$ & $150 \mathrm{hi}$ & $12.4 \mathrm{a}-\mathrm{f}$ & $126 \mathrm{f}-\mathrm{i}$ \\
\hline Sunburst & $558 \mathrm{a}-\mathrm{h}$ & $287 \mathrm{a}-\mathrm{g}$ & $16.0 \mathrm{a}-\mathrm{e}$ & $85 \mathrm{i}$ \\
\hline Sundance & $620 a-f$ & $377 \mathrm{ab}$ & $17.5 \mathrm{ab}$ & $181 \mathrm{~b}-\mathrm{e}$ \\
\hline Sunsation & $481 \mathrm{c}-\mathrm{i}$ & 187 ghi & $16.7 \mathrm{a}-\mathrm{d}$ & $233 \mathrm{a}$ \\
\hline Yellow Bird & $644 a-d$ & $258 \mathrm{~b}-\mathrm{i}$ & $14.1 \mathrm{a}-\mathrm{f}$ & $147 \mathrm{~d}-\mathrm{g}$ \\
\hline Yellow Lantern & $667 \mathrm{abc}$ & 327 a-e & $17.6 \mathrm{ab}$ & $213 \mathrm{ab}$ \\
\hline
\end{tabular}

${ }^{\mathrm{z}}$ Height, canopy width, and trunk diameter were measured in Dec. 2015. Canopy width was an average from two perpendicular measurements made from dripline to dripline. Trunk diameter was measured $15 \mathrm{~cm}$ above the soil surface; $1 \mathrm{~cm}=0.3937$ inch.

${ }^{y}$ Average leaf area was determined from five randomly selected mature leaves located with 18 inches $(45.7 \mathrm{~cm})$ from the tip of the branch located in the upper top of canopy in June $2014 ; 1 \mathrm{~cm}^{2}=0.1550 \mathrm{inch}^{2}$.

xMeans within columns followed by the same letter are not significantly different as determined by Duncan's multiple range test at $P \leq 0.05$.

2008 until 2015. In some years, unseasonably warm periods caused the flowers to mature quickly, thus the flowering period was shorter; whereas, in other years, late spring frosts resulted in poor flowering and delayed leaf-out. 'Goldfinch' was the earliest cultivar to bloom in mid-to-late March, followed by Butterflies and Golden Pond. 'Golden Pond', 'Sunsation', and 'Elizabeth' had flowering periods that frequently lasted up to 3 weeks; however, the best floral display was often during the middle of the flowering period when the most flowers were open. 'Yellow Lantern' and 'Gold Star' had the shortest flowering period that lasted about 1 week, then had a distinct period of time before leaf-out occurred. The flowers on 'Honey Liz' were the last to open; however, the flowering period overlapped with 'Sunsation', 'Yellow Bird', and 'Judy Zuk'. In most years, 'Sunsation' flowered about 1 week before 'Judy Zuk' and 'Yellow Bird'. Though flower numbers were not quantified, 'Yellow Bird' appeared to be the most floriferous in the evaluation and may have had more than twice the number of flowers than other cultivars.

With many cultivars, such as Butterflies, Carlos, Gold Star, Goldfinch, Sun Ray, Sundance, and Yellow Lantern, there was a distinct period between flowering and leaf-out. These cultivars bloomed in late March and leaf-out did not occur until early to mid-April. Cultivars, Solar Flair, Sun Spire, Sunburst, and
Sunsation, had overlapping periods of flowering and leaf-out, but leaf-out did not affect the floral display. However, 'Judy Zuk' and 'Yellow Bird', two of the latest cultivars to flower, often had the floral display concealed by the foliage, which unfurled during the peak flowering period.

One of the challenges with yellowflowering magnolias was to determine flower color. Flower color has been reported to vary from year to year, or in certain climates, not to develop fully (Knox, 2002). With many cultivars, the intensity of the yellow quickly fades into a soft creamy color, so flower color can ultimately change from day to day. Also, the color varied markedly from the inner side to the outer side of the tepal and from the basal end to the tip. Some cultivars (e.g., Sunsation) had flowers with an incursion of pink. Though not quantified, warmer spring temperatures resulted in less yellow color intensity than in cooler spring seasons. In this test, the RHC Color Chart was used to determine the color on the outside of the tepal and the author found differences compared with colors reported in the Magnolia Cultivar Checklist (Magnolia Society, 2010) and other notable sources (Fare, 2011). This is to be expected due to the maturity of the flower, location of the plant, and expected differences from year to year (Knox, 2002). The portable spectrophotometer used in this test to measure color intensity, also showed differences in color from tepal to tepal, plant to plant, and year to year; even though a more precise color was measured than what was dependent on the human eye with the RHS color chart. These readings were based on a threedimensional space with three axes, $x, y$, and $z$. The $x$ axis measured a positive value for red and a negative value for green. The $y$ axis is the light (100) and dark axis (0), and the $z$ axis measured a positive value for yellow and a negative value for blue. The higher the yellow value the more intense the yellow color. For instance, 'Gold Star', 'Golden Gala', 'Stellar Acclaim', 'Sun Spire', and 'Sundance' routinely had the lowest yellow color values in the low 20s on the outside of the tepal; whereas, 'Daphne', 'Judy Zuk', and 'Yellow Bird' had the highest yellow color readings in the upper 30 s on the outside of the tepal. 
Since the initial planting, there were some distinct differences in height growth, which ranged from 345 to $708 \mathrm{~cm}$ among cultivars (Table 1). Carlos and Gold Star were two of the tallest cultivars in the test (708 and $699 \mathrm{~cm}$, respectively), compared with Butterflies, Gold Cup, Golden Gift, Golden Pond, Golden Rain, Green Bee, Honey Liz, Koban Dori, Skyland's Best, and Sunsation, which ranged from 345 to $481 \mathrm{~cm}$.

Canopy width was calculated from an average of two perpendicular measurements made from dripline to dripline (Table 1). Canopy width ranged from 135 to $401 \mathrm{~cm}$ among cultivars with distinct canopy shapes prominent with several cultivars. 'Gold Star' had the widest canopy at $401 \mathrm{~cm}$, but was similar to 'Carlos', 'Golden Gala', 'Lois', 'Solar Flair', 'Stellar Acclaim', 'Sunburst', 'Sundance', and 'Yellow Lantern'. Some cultivars (Anilou, Banana Split, Butterflies, Gold Cup, Golden Pond, Golden Rain, Goldfinch, Green Bee, Honey Liz, Judy Zuk, Koban Dori, Petit Chicon, Skyland's Best, Sun Spire, and Sunsation), had less than half the canopy width of Gold Star, but in relation to their height growth may eventually be oval or broadly upright. 'Gold Cup', 'Judy Zuk', and 'Sun Spire' had a distinct upright growth habit in relation to their height that will probably become more distinct with age.

To ensure all trunk diameters were measured above the bud union, trunks were measured $15 \mathrm{~cm}$ above the soil line. Trunk diameters ranged from 7.4 to $18.4 \mathrm{~cm}$ (Table 1). 'Carlos', 'Gold Star', 'Golden Gala', 'Lois', 'Sundance', and 'Yellow Lantern' had trunk diameters larger than cultivars, Butterflies, Daphne, Gold Cup, Golden Pond, Golden Rain, Green Bee, Honey Liz, Koban Dori, Petit Chicon, or Skyland's Best. Some cultivars (e.g., Golden Gala and Gold Star) had trunk diameters greater than twice the size of Golden Pond, Golden Rain, Green Bee, Honey Liz, and Koban Dori.

The complexity of the parental lines with many of the cultivars probably had some effect on growth as well as the rootstock. The author observed that the rootstock and scion growth was occurring at different rates with several cultivars. Inquiries were made to the sources of the original magnolia purchases about the rootstock, but a lack of records made it impossible to confirm species and or cultivar. Overgrowth or undergrowth of the scion may be related to genetic tendency for growth or related to a problem with incompatibility with the rootstock, which would result in poor growth (Hartmann et al., 2002).

Leaves on the yellow-flowering magnolias vary in size (Table 1). 'Carlos', 'Golden Gala', 'Sunsation', and 'Yellow Lantern' are among the cultivars with the largest leaves. The foliage presents a very coarse textured canopy and may result in concerns with fall leaf litter. In contrast, 'Butterflies', 'Daphne', 'Gold Star', 'Golden Gift', 'Green Bee', 'Koban Dori', 'Skyland's Best', 'Stellar Acclaim', and 'Sunburst' had some of

the smallest leaves among the cultivars in the evaluation.

Powdery mildew developed into a serious problem in the evaluation [Table 2 (only data shown are from Oct. 2015)]. This foliar disease appeared naturally and pressure was consistently high in most years. No attempts were made to apply preventative fungicides in the evaluation. There were significant differences among cultivars with powdery mildew. In Oct. 2015, all cultivars had some incidence of powdery mildew on the foliage; however, the percent coverage of powdery mildew varied plant cultivar. 'Golden Sun', 'Green Bee', 'Solar Flair', 'Stellar Acclaim', 'Sunburst', and 'Yellow Bird' had greater than $40 \%$ of the leaf area affected with powdery mildew. Of those cultivars, Green Bee, Stellar

Table 2. Percent coverage of powdery mildew on individual leaves and on plant canopy of yellow flowering magnolia cultivars in Oct. 2015 at McMinnville, TN (USDA Hardiness Zone 6b).

\begin{tabular}{|c|c|c|}
\hline & $\begin{array}{l}\text { Powdery mildew on } \\
\text { individual leaves }\end{array}$ & $\begin{array}{c}\text { Powdery mildew on } \\
\text { plant canopy }\end{array}$ \\
\hline Cultivar & $(\%$ coverage $)$ & \\
\hline Anilou & $24.8 \mathrm{cde}^{\mathrm{z}}$ & $50.0 \mathrm{~b}-\mathrm{h}$ \\
\hline Banana Split & $20.0 \mathrm{cdef}$ & $20.0 \mathrm{hij}$ \\
\hline Butterflies & 10.0 ef & $17.0 \mathrm{ij}$ \\
\hline Carlos & 13.0 def & 20.0 hij \\
\hline Daphne & $30.0 \mathrm{~cd}$ & $35.0 \mathrm{e}-\mathrm{j}$ \\
\hline Elizabeth & 10.0 ef & $16.7 \mathrm{ij}$ \\
\hline Gold Cup & $30.0 \mathrm{~cd}$ & $46.7 \mathrm{c}-\mathrm{i}$ \\
\hline Gold Star & $15.0 \mathrm{def}$ & $66.7 \mathrm{a}-\mathrm{d}$ \\
\hline Golden Gala & $43.0 \mathrm{bcd}$ & $27.5 \mathrm{~g}-\mathrm{j}$ \\
\hline Golden Gift & 20.0 cdef & $40.0 \mathrm{~d}-\mathrm{j}$ \\
\hline Golden Pond & $43.0 \mathrm{bcd}$ & $30.0 \mathrm{f}-\mathrm{j}$ \\
\hline Golden Rain & $20.0 \mathrm{cdef}$ & $58.3 \mathrm{a}-\mathrm{f}$ \\
\hline Golden Sun & $60.0 \mathrm{ab}$ & $35.0 \mathrm{e}-\mathrm{j}$ \\
\hline Goldfinch & $30.0 \mathrm{~cd}$ & $25.0 \mathrm{~g}-\mathrm{j}$ \\
\hline Green Bee & $47.0 \mathrm{abc}$ & $83.3 \mathrm{a}$ \\
\hline Honey Liz & $43.0 \mathrm{bcd}$ & $80.0 \mathrm{ab}$ \\
\hline Judy Zuk & $17.0 \mathrm{def}$ & $23.3 \mathrm{~g}-\mathrm{j}$ \\
\hline Koban Dori & $41.0 \mathrm{bcd}$ & $70.0 \mathrm{abc}$ \\
\hline Lois & $20.0 \mathrm{cdef}$ & $28.3 \mathrm{f}-\mathrm{j}$ \\
\hline Petit Chicon & $30.0 \mathrm{~cd}$ & $21.7 \mathrm{~g}-\mathrm{j}$ \\
\hline Skyland's Best & $42.0 \mathrm{bcd}$ & $77.5 \mathrm{ab}$ \\
\hline Solar Flair & $60.0 \mathrm{ab}$ & $35.0 \mathrm{e}-\mathrm{j}$ \\
\hline Stellar Acclaim & $47.0 \mathrm{abc}$ & $85.0 \mathrm{a}$ \\
\hline Sun Ray & $13.0 \mathrm{def}$ & $21.7 \mathrm{~g}-\mathrm{j}$ \\
\hline Sun Spire & $3.0 \mathrm{f}$ & $13.3 \mathrm{ij}$ \\
\hline Sunburst & $50.0 \mathrm{abc}$ & $61.7 \mathrm{a}-\mathrm{e}$ \\
\hline Sundance & $10.0 \mathrm{ef}$ & $35.0 \mathrm{~g}-\mathrm{j}$ \\
\hline Sunsation & $43.0 \mathrm{bcd}$ & $51.7 \mathrm{~b}-\mathrm{f}$ \\
\hline Yellow Bird & $63.0 \mathrm{a}$ & $71.7 \mathrm{abc}$ \\
\hline Yellow Lantern & $30.0 \mathrm{~cd}$ & $26.7 \mathrm{~g}-\mathrm{j}$ \\
\hline
\end{tabular}

${ }^{\mathrm{z}}$ Values are the means of three replicate plots. Means within columns followed by the same letter are not significantly different as determined by Duncan's multiple range test at $P \leq 0.05$. 
Acclaim, Sunburst, and Yellow Bird had over $60 \%$ of the canopy affected. Another cultivar, Gold Star, had 15\% of individual leaf surface affected with powdery mildew, but over $66 \%$ of the canopy was affected. Powdery mildew covered less than $20 \%$ on both the foliage and plant canopy 'Banana Split', 'Butterflies', 'Carlos', 'Elizabeth', and 'Sun Spire'.

\section{Conclusions}

A comprehensive replicated evaluation of new and familiar yellowflowering magnolias in one location will benefit magnolia connoisseurs, the nursery industry and prospective plant breeders. As yellow-flowering magnolias become more widely known, many cultivars in this evaluation may be less popular and will serve only as breeding lines for developing improved cultivars. Time of flowering is critical for plants in USDA Hardiness zones 6 and 7 due to early spring frosts (and freezes) and will be the deciding factor for the success of many yellow-flowered cultivars (Tubesing, 1998). The palette of yellow color is well represented with the magnolia cultivars from borderline creamy yellow to distinctly yellow in color (Cover, 2009). In this evaluation, cultivars that flowered after the threat of spring frosts also leafed-out during the flowering period which decreased the visibility of flowering and had less floral impact than cultivars that bloomed earlier in the spring.

\section{Literature cited}

Cover, S. 2009. The performance of yellow magnolia hybrids in a modified continental climate. Magnolia 44(86):5-17.

Fare, D.C. 2011. A comprehensive evaluation of yellow-flowering magnolias. J. Magnolia Soc. Intl. 46:13-29.

Hartmann, H.T., D.E. Kester, F.T. Davis, Jr., and R.L. Geneve. 2002. Hartmann and Kester's plant propagation: Principles and practices. 7th ed. Princeton Hall, Upper Saddle River, NJ.

Knox, G.W. 2001. New and improved deciduous magnolia cultivars. Comb. Proc. Intl. Plant Prop. Soc. 51:601-603.

Knox, G.W. 2002. Yellow-flowering magnolias for Florida and the Gulf Coast. Proc. Southern Nursery Assn Res. Conf. 47:637-639.

Magnolia Society International. 2010. Magnolia cultivars checklist, 7 Mar. 2016. <http://www.magnoliasociety.org/ checklist_ndx.html>.

Royal Horticultural Society (RHS). 2007. Royal Horticultural Society colour chart. 5th ed. Royal Hort. Soc., London, UK.

Tubesing, C. 1998. Sorting out the yellow magnolias. Comb. Proc. Intl. Plant Prop. Soc. 48:312-314.

U.S. Department Agriculture. 2014. 2014 Census of horticultural specialties. 17 Mar. 2016. <http://www.agcensus. usda.gov>. 